УДК 811.161.2’373:641

\title{
ЛІНГВОКУЛЬТУРНА СПЕЦИФІКА НАЙМЕНУВАНЬ ЇЖІ В ТЕКСТАХ СУЧАСНОЇ ЖІНОЧОЇ МАНДРІВНОЇ ПРОЗИ
}

\author{
Ірина Маслясва \\ Криворізький державний педагогічний університет \\ Kryvyi Rih State Pedagogical University \\ пр. Гагаріна, 54, Кривий Ріг, 50086, Україна \\ masliaievairyna@gmail.com
}

Масляєва I. Лінгвокультурна специфіка найменувань їжі в текстах сучасної жіночої мандрівної прози

У статті досліджено власне українські й іншокультурні назви їжі на матеріалі текстів української сучасної жіночої мандрівної прози. Зокрема акцентовано на взаємозв'язку культуронімів з гастрономічною картиною світу. 3'ясовано лінгвокультурні параметри найменувань їжі, виявлено запозичену та національно-специфічну лексику (установлено джерела поповнення концептосфери “Їжа"). Окреслено низку факторів, які безпосередньо впливають на лінгвокультурні особливості найменувань, пов'язаних із продуктами харчування.

Ключові слова: найменування їжі, гастрономічна картина світу, ксенонім, культуронім, сучасна українська жіноча проза, мандрівна проза.

Масляева И. Лингвокультурная специфика наименований пищи в текстах современной женской путевой прозы

В статье исследуются собственно украинские и инокультурные названия пищи на материале текстов современной украинской женской путевой прозы. В частности акцентируется внимание на взаимосвязи культуронимов с гастрономической картиной мира. Выясняются лингвокультурные параметры наименований пищи, дифференцируются заимствованную и национально-специфическую лексику (установлено источники пополнения концептосферы “Еда"). Анализируется ряд факторов, которые непосредственно влияют на лингвокультурные особенности наименований, связанных с продуктами. питания.

Ключевые слова: наименования пищи, гастрономическая картина мира, ксеноним, культуроним, современная украинская женская проза, путевая проза.

Masliaieva I. Linguocultural features of food names in texts of modern women's travel prose

The article deals with the process of studying of glutonic names that represent the features of the glutonic discourse which there is an object of interest of 
scholars not only from the point of view of linguistics and its individual areas, such as: linguoculture, linguistics, linguistic and semiotics, but also cultural studies, sociology and literary studies.

The article investigates the actual Ukrainian and other cultural names of food on the material of texts of Ukrainian contemporary women's travel prose. In particular, the emphasis is placed on the interconnection of cultural onyms with a gastronomical picture of the world. The linguistic and cultural parameters of food names have been determined, borrowed and national-specific vocabulary has been identified (the source of replenishment of the concept sphere "Food" is established). There are a number of factors that directly influence on the linguistic and cultural peculiarities of the names related to food products.

The linguistic and cultural specificity of the food names in the texts of Ukrainian contemporary women's prose is governed by a number of cultural factors: natural, cultural, historical, socio-economic, etc. Food names are a culturally significant layer of vocabulary that demonstrates the interconnectedness and enrichment of cultures. In particular, the enrichment of European (and not only) cultural and culinary ideas that represent the linguistic and cultural heritage of neighboring and more distant nationalities. That is why a considerable number of these names have long been stabilized in the mind of the average speaker through assimilation processes. Ukrainian contemporary women's travel prose is a valuable source not only for the study of the "Food" concept from the standpoint of linguoculture, but also for its complex study.

Key words: denomination of food, gastronomical picture of the world, xenonym, culturonym, modern Ukrainian female prose, travel prose.

Постановка проблеми, аналіз останніх досліджень та публікацій. Реалії сьогодення демонструють те, що найменування, так чи так пов'язані із концептосферою “Їжа", дедалі частіше стають предметом дослідження. Неабиякого значення в цьому аспекті набувають наукові розвідки відповідних назв із позиції лінгвокраїнознавства, лінгвокультурології, лінгвосеміотики, де актуальним є зіставне вивчення назв їжі, які, своєю чергою, маніфестують специфіку культури іншомовних етноспільнот. Очевидно, таке зацікавлення зумовлене інтенсивним розвитком міжнародних контактів в умовах глобалізації між носіями тих чи тих мов у різноманітних сферах життєдіяльності, зокрема й у сфері глютонії. Так, Л. Єрмакова та Г. Тазбулатова здійснили опис лінгвокультурних особливостей найменувань їжі на матеріалі англійської мови, К. Федорова - корейської, М. Ундрицова російської, англійської, французької і грецької, Г. Боваєва калмицької, російської й німецької мов. 
Зважаючи на наявність низки грунтовних праць як монографічного, так i дисертаційного зразків, у яких систематизовано іншомовний матеріал, уважаємо за потрібне здійснити опис лінгвокультурних особливостей назв їжі саме на українськомовній джерельній базі. Примітним є те, що наразі актуальності набуває всебічне вивчення різноманітних назв страв і напоїв, репрезентованих у творах сучасної художньої української літератури (учені здебільшого аналізують структурно-семантичні, типологійні, семіотичні характеристики відповідних найменувань). Проте однією з не менш цікавих за наявністю фактичного матеріалу, що ілюструє специфіку гастрономічної картини світу, $є$ й так звана українська “сучасна жіноча мандрівна проза" (за витлумаченням Є. Моштаг [Moshtah / Моштаг 2017 : 5]), дослідження якої потребує особливої уваги.

Мета й завдання дослідження. Мета статті полягає передовсім у з'ясуванні й аналізі лінгвокультурних особливостей найменувань їжі, засвідчених у текстах української “сучасної жіночої мандрівної прози” (Ірена Карпа "Baby travel. Подорожі з дітьми, або Як не стати куркою”, Ірен Роздобудько “Мандрівки без сенсу і моралі”, Марина Гримич "Бранзолія").

Виклад основного матеріалу. Сьогодні, як і багато років тому, мова відіграє важливу роль у формуванні національного характеру, етнічної спільноти, нації загалом, оскільки не лише зберігає культуру, але й передає іï 3 покоління в покоління упродовж багатьох віків. Як відомо, у різних мовах є спеціальні терміни для позначення об'єктів матеріальної культури. Наявність відповідних дефініцій пов'язана 3 побутуванням особливих звичаїв і специфічної системи цінностей, що характерні для того чи того етносу. Найменування їжі являють собою один із об'єктів матеріальної культури, у якому знаходить своє відображення дух народу. Станом на сьогодні в науковій царині досі не вироблено єдиноприйнятої назви, яка б позначала об'єкти матеріальної культури (натрапляємо на паралельне вживання таких термінів, як-от: безеквівалентна лексика, фонова лексика, національні словесні образи, культуреми, культуроніми і т. ін.). Нам найбільше імпонує 
термін “культуронім”, який запропонував російський інтерлінгвокультуролог В. Кабакчи. У розумінні науковця “культуроніми” - найменування елементів будь-яких культур, незалежно від певної мови [Kabakchy / Кабакчі 2011:13]. Цілком закономірно, що назви їжі ми уналежнюємо до культуронімів, адже відповідні найменування великою мірою ретранслюють ту чи ту культуру. Підтвердженням цього може слугувати контекст: Якби мене спитали: який культурний символ сучасної сільської спільноти півдня Бразилії (не лише української) найбільше характеризує ї̈ дух $і$ нащіональний характер, я б сказала: ие шімарон (chimarrão) - давній, доєвропейський напій з місиевої рослини ерва мате або просто ерви (в португальській мові еrva-таte) (1, с. 93).

Зважаючи на те, що аналізовані тексти належать до мандрівної прози, дібраний фактичний матеріал демонструє симбіоз різних культур, а відтак - засвідчує наявність як іншокультурних, так i власне українських найменувань їжі (зауважимо: під поняттям “їжа” розуміємо те, що їдять і п'ють; харчі [5]). Пор.: Звісно ж, я з задоволенням наминаю і вареники, i борщ, і голубці-смачно ж, зараза! - але тільки в гостях (2); Традиційна малайська страва, яку подають неодмінно, курячий бульйон з овочами, щзо має назву “айя” (3). Хоч власне українські найменування їжі представлені меншою мірою, проте передають, окрім культурної специфіки, ще й мовні особливості: хлібець-удалещь, хлібчик (2). Напр.: Аж поки зовсім випадково на дні валізи хтось із них не знайшов шматочок хлібця-удальця цे переможно не заявив: "Сіпки!" То, виявлясться, був простий собі “хлібчик”, що після “сіпок” став “сіпчиком”...(2). Подекуди власне українські номінації увиразнюються за допомогою прикметникових поширювачів із значенням обрядовості, як-от: весільний коровай / хліб (У цей новіший - “сиенарій” вживання їжі вклинюються старі украӥнські звичаї: розподіл весільного хліба і розподіл весільного короваю, щчо є двома різними ритуальними прочедурами $(1$, c. 120). Не менш цікавими $є$ й так звані крос-культурні найменування, семантичне значення яких поєднує елементи двох кулінарних практик: Відомі також украӥнсько-бразильські

() І. Масляєва, 2019. 
страви із маніоки - балабушки, вареники з маніоки, варена або підсмажена маніока тощо (1, с. 53). Варто зазначити, що письменниці часто вдаються до пояснення лексем, які $\epsilon$ незрозумілими читачеві. Тому в межах текстів натрапляємо на авторські коментарі стосовно того чи того найменування. Напр.: Третє місие в моєму рейтингу бразильських смаків займає маніока. Дивовижний продукт: за смаком (і способом приготування) нагадуе картоплю, на вигляд плід нагадує видовжений кокосовий горіх, а сама рослина (тобто зелена ї̈ частина), коли виростає, - дуже подібна на коноплю (1, с. 51). До того ж фіксуємо й певні коментарі лінгвістичного характеру щодо особливостей вимови відповідної назви: Маніока (або помісцевому мандіока) - надзвичайно цікавий продукт з точки зору дослідника українсько-бразильської регіональної субкультури (1, с. 51); Українці в Бразилї вимовляють це слово як манджсоха (маньджьоха) (1, с. 52). Як бачимо, особливості вимови аналізованого найменування здебільшого залежать від регіонального розмежування.

Дібраний фактичний матеріал уможливлюює думку про те, що на співіснування іншокультурних та власне українських назв їжі впливає явище міжкультурної комунікації, яке сьогодні $\epsilon$ доволі популярним. Як результат, відбувається стирання меж між тими чи тими культуронімами під впливом узаємодії різних кулінарних практик, що зумовлює процеси крос-культурної комунікації та сприяє збагаченню лексичного складу мовкомунікантів [Masliaieva / Масляєва : 57]. Так, у творах сучасної жіночої мандрівної прози наявні лексичні запозичення на позначення назв їжі, що повністю інтегрувалися в національномовну картину світу українців і вже не викликають ефект “культурного шоку” [Gashimov/ Гашимов 2005: 5], сприймаються як таке, що є само собою зрозумілим. Варто, очевидно, наголосити на тому, що В. Кабакчі називає відповідні дефініції “базовими ксенонімами”, тобто одиницями, що описують пласт спеціальної іншомовної лексики, який увійшов до складу загальнодоступної за допомогою способу транслітерації [Kabakchy / Кабакчі 2011 : 14]. Тому зазвичай такі номени подаються письменницями без пояснення, оскільки їхнє 
смислове навантаження $є$ зрозумілим навіть пересічному читачеві: “Американська кухня” - поняття досить незрозуміле. Певною мірою, суто національний винахід - ие все, щчо робиться в “Макдонапъдзі": чизбургери, гамбургери, чіпси...(3).

Окрему групу найменувань їжі становлять лексеми, які прийнятні в українськомовному суспільстві, але очевидним $є$ те, що вони завжди позначали, позначають i, можливо, будуть позначати виключно іншокультурні реалії, оскільки статус таких назв має безпосередню залежність від місця та умов, у яких вирощується той чи той продукт. До таких номенів належать переважно назви фруктів, як-от: маракуйя, гуава, кошлаті горішки лічі, карамболь, манго, ананас тощо. Напр.: А от щодо фруктів... Побувавши на так званій "фермі прянощів” на острові Пенанг, з подивом і гордістю розумієм, шьо навіть найекзотичніші фрукти, скажімо кошлаті горішки лічі, не кажучи вже про ананаси, карамболі та манго, можна знайти і в наших супермаркетах. Хіба щзо смакуватимуть вони трохи “другорядно” (3). Одним із елементів представлення лінгвокультурних особливостей найменувань їжі $\epsilon$ наявність у текстах подвійної номінації (напр., десь-не-десь авторки послуговуються англомовним, французькомовним еквівалентом певної назви поряд із українським відповідником). Найкраще така взаємозаміна простежується через контекст: Перше місие в моєму рейтингу смаків займає маракуйя. Англійською мовою вона називається passion fruit, тобто фрукт пристрасті, однак насправді ї̈ в Бразилї вважають плодом заспокійливої дії, зокрема, рекомендують вживати перед сном (1, с. 48-49). Ііноді письменниці вдаються до дослівного тлумачення номенів із подальшим поясненням, що, своєю чергою, покращує розуміння деяких лінгвокультурних особливостей різних етноспільнот. Як слушно зазначав американський лінгвіст Б. Уорф, носії різних мов по-різному сприймають факти і явища, оскільки ці факти і явища по-різному виражені та сформульовані в їхніх мовах [Uorf / Уорф 1960 : 34]. Саме тому первинне семантичне значення запозиченої лексеми не завжди збігається iз вторинним.

() І. Масляєва, 2019. 
Досліджувані тексти, окрім базових ксенонімів, містять широкий спектр “спеціальних словникових ксенонімів”, тобто лексем, які є незрозумілими пересічному читачеві й потребують пояснення [Kabakchy / Кабакчі 2011 :15]. Напр.: icn. churrasco шураску / шураска (бразильська національна страва, грильоване м'ясо телятини, що засмажується великими шматками), івр. оııп - xyмyс (традиційна їжа ізраїльської кухні та країн Близького Сходу, яка складається із нутового пюре й кунжутної пасти), івр. קוגל - кугл (традиційна страва ізраїльської кухні, що являє собою запіканку й передбачає поєднання різних інгредієнтів), imaл. brodetto - броде (національний хорватський суп, який містить поєднання різних видів риби), хінді गुलाब जामुन - гулаб-джамун (десерт у вигляді обсмажених на фритюрі кульок із сухого молока, поширений в індійській кулінаріï), im. cassatella - касатела (традиційний сицилійський торт), нiм. schnaps - шнаnc (німецький міцний алкогольний напій, що виробляється переважно на основі перегону зерна або картоплі), фpp. parfait - nappe (заморожений десерт зі збитих вершків, цукру й ванілі), хіндi बिरयानी - бірьяні (друга страва із рису та спецій, поширена у країнах Південної Азії), хіндi मसाला - масала (індійська назва суміші спецій), фp. la tapenadei moniнада (густий соус прованської кухні, виготовлений із оливок) і т. ін. Напр.: Діти в Києві їли всі ці бірьяні $і$ масали аж гай шумів, а от на місиі, в Кералі, Кора змусила мене впасти в депресію: навідріз відмовилася від всього, щчо бодай якось пахло “не по-нашому” (2); До всієї цієї краси, щееро викладеної на величезному тарелі, додається хвойний шнапс за давнім рецептом вікінгів, а на десерт - морквяний пиріг з білим та чорним шоколадом (3); Якщчо чесно, то саме шураска (так ї̈ звуть украӥнці) мала б стати номером один у моєму рейтингу бразильських смаків (1, с. 55).

Доволі часто зміст наведених вище найменувань важко витлумачити без спеціальних знань і використання довідкової літератури. У разі незнання “іншокультурних кодів" виникає “комунікативна фрустрація” [Gashimov/ Гашимов 2005: 5]. Це розуміють і самі авторки, а тому подають необхідні 
коментарі в межах того чи того тексту. Напр.: Чай мате - ие гарячий тонізуючий напій, який вживають подібно до чорного чи зеленого чаю, тобто з чашки (1, с. 93); А шімарон - цее, на наш хлопський розум, той самий чай мате, лише вживається він принципово інакше (1, с. 93); До речі, хумус - традиційна їжа ізраїльської кухні. Це така собі паста з бобових. Сама по собі вона не має певного смаку, все залежить від різних приправ і додатків. ї̈ накладають всередину піти - круглого плаского хлібия (3); При иььому філантропи розмістили їх у зоні терас кав'ярень $і$ барів, так, аби і змучена мама, спустивши дитятко з поводка, могла собі випити якоӥсь клари (пивний коктейль) чи зимного білого вина (2).

Іноді загальновідомим $є$ значення стрижневого компонента, а поширювальний потребує відповідних знань, якот: Нині суто американською стравою можна вважати супи 3 розряду “клем-чаудер” (3), де супи з розряду “клем-чаудер” “загальна назва кількох видів традиційного американського супу, звареного 3 молюсків і бульйону, із додаванням або молока - новоанглійський клем-чаудер, або помідорів манхеттенський клем-чаудер".

Поодиноко натрапляємо на назви їжі, мовне оформлення яких створює ефект каламбуру: Матроси, між тим, уже приготували “легкий перекус", котрий виявився не таким і легким: смажена риба різних сортів, кілька різновидів салатів та гарнірів і м'ясна національна страва - “кофта”, котлети по-нашому (3), де запозичений номен кофта являє собою не елемент одягу, а - традиційну страву країн Близького Сходу, яка готується переважно з баранини. Наведений приклад передовсім демонструє неправильне зчитування культурних кодів. 3-поміж відповідних найменувань можемо виокремити й такі: плескавиці, чевапчичі. Реципієнт, який уперше бачить названі лексеми, може по-різному витлумачити їх, грунтуючись при цьому лише на семантичному значенні цих слів. Однак плескавиці - назва страви, яка має вигляд круглої пласкої котлети 3 рубленого м'яса, а чевапчичі - найменування смажених ковбасок 3 перемеленого м'яса 3 цибулею та приправами (обидві страви поширені на Балканах). Напр.: 
На четвертий день імені Зашитої ноги ми, доївши всі плескавиці й чевапчичі на грилі, зібрали свої бебехи й запакувалися в цей майже відмитий “Пежо 3008” (2).

Варто, очевидно, акцентувати й на тому, що більшість ксенонімів (і базові, і спеціально словникові) потрапили в українську мову (так само, як і в інші) за допомогою калькування. Так, наприклад, лексеми на позначення різновидів макаронних виробів (спагеті, тальятеле, ньокі) “мігрували” в інші мови з італійської, а лексеми на позначення сирів із пліснявою (щевр, камамбер, бльо-де-брес) - iз французької. Напр.: Макарони у всій своїй різноманітності спагеті, тальятеле, ньокі тощчо - це те, чим варто запастися на випадок подорожі чи ядерної війни (2); Вічний шевр, камамбер, бльо-де-брес красиво займають позииії на скелястих вистуnax co^te sauvage (2). Цілком закономірним $\epsilon$ те, що на так звану “міграцію" найменувань впливають процеси глобалізації, які стирають межі між кулінарними практиками різних етносів.

\section{Висновки та перспективи подалыших наукових} розвідок. Отже, можна зробити висновок: лінгвокультурна специфіка найменувань їжі, наявних у текстах української сучасної жіночої мандрівної прози, регламентується низкою культурологічних факторів: природніми, культурноісторичними, соціально-економічними і т. ін. Назви їжі - це культурно значущий пласт лексики, який демонструює узаємозв'язок і взаємозбагачення культур. Саме тому значна кількість цих назв давно закарбована у свідомості середньостатистичного мовця завдяки процесам асиміляції, пов'язаних із поширенням, а згодом - i 3 інтеграцією європейських (і не тільки) культурно-мистецьких та кулінарних ідей, що репрезентують лінгвокультурні надбання як сусідніх, так і більш віддалених народів.

Українська сучасна жіноча мандрівна проза являє собою цінне джерело не лише для студіювання концептосфери “Їжа" 3 позиції лінгвокультурології, але й для комплексного іiі дослідження. 


\section{Література}

1. Гашимов Э. А. Структурно-семантические и прагматические характеристики английского лингвокультурного кода (на материале лексикофразеологического поля “Продукты питания") : автореф. дис. ... канд. филол. наук : 10.02.04. Самара, 2005. $31 \mathrm{c}$.

2. Кабакчи В. В. Введение в интерлингвокультурологию. Язык $u$ межкультурная коммуникация : материалы II Международной науч.-практ. конференции. Великий Новгород, 2011. Т. 1. С. 11-19.

3. Масляєва I. В. Назви страв у сучасному художньому мовленні : структурно-семантичний та функціонально-стилістичний аспекти : дис. ... магістр філол. наук. Кривий Ріг, 2018. 100 с.

4. Моштаг Є. С. Стилістично-дискурсивна характеристика сучасної жіночої мандрівної прози : автореф. дис. ... канд. філол. наук : 10.02.01. Харків, 2017. $20 \mathrm{c}$.

5. Словник української мови : в 11-и томах. URL : http://ukrlit.org/slovnyk/ slovnyk_ukrainskoi_movy_v_11_tomakh

6. Уорф Б. Л. Отношение норм поведения и мышления к язику. История языкознания XIX и XX веков в очерках и извлечениях. Моссква, 1960. Ч. II. C. $24-98$.

\section{Список використаних джерел}

1. Гримич М. В. Бранзолія : подорожні записки. Київ, 2015. 156 с.

2. Карпа I. I. Baby travel. Подорожі 3 дітьми, або Як не стати куркою. Харків, 2014. 208 c. URL : https://www.e-reading.club/bookreader.php/1054373/ Karpa_Baby_travel._Podorozhi_z\%A0ditmi\%2C_abo_Yak_ne_stati_kurkoyu.html

3. Роздобудько I. В. Ранковий прибиральник. Київ, 2015. 160 с. URL : https://www.rulit.me/books/rankovij-pribiralnik-read-374098-1.html

\section{References}

1. Gashimov Y. A. Strukturno-semanticheskie i pragmaticheskie harakteristiki angliyskogo lingvokulturnogo koda (na materiale leksiko-frazeologicheskogo polya "Produktyi pitaniya") : avtoref. dis. ... kand. filol. nauk : 10.02.04. Samara, 2005. $31 \mathrm{~s}$.

2. Kabakchy V. V. Vvedenye v ynterlynhvokulturolohyiu. Yazyk v mezhkulturnoy kommunykatsyi : materyaly II Mezhdunarodnoi nauch.-prakt. konferencii.Velykyi Novhorod, 2011. T. 1. S. 11-19.

3. Masliaieva I. V. Nazvy strav u suchasnomu khudozhnomu movlenni : strukturno-semantychnyi ta funktsionalno-stylistychnyi aspekty : dys. ... mahistr filol. nauk. Kryvyi Rih, 2018. 100 s.

4. Moshtah Ye. S. Stylistychno-dyskursyvna kharakterystyka suchasnoi zhinochoi mandrivnoi prozy : avtoref. dys. ... kand. filol. nauk : 10.02.01. Kharkiv, 2017. $20 \mathrm{~s}$.

5. Slovnyk ukrainskoi movy : v 11-i tomakh. URL : http://ukrlit.org/slovnyk/ slovnyk_ukrainskoi_movy_v_11_tomakh

6. Uorf B. L. Otnoshenye norm povedenyia $\mathrm{v}$ myshlenyi $\mathrm{k}$ yazyku. Istoryia yazykoznanyia XIX i XX vekov v ocherkakh i yzvlechenyiakh. Mosskva, 1960. Ch. II. S. 24-98. 


\section{Spysok vykorystanykh dzherel}

1. Hrymych M. V. Branzoliia : podorozhni zapysky. Kyiv, 2015. $156 \mathrm{~s}$.

2. Karpa I. I. Baby travel. Podorozhi z ditmy, abo Yak ne staty kurkoiu. Kharkiv, 2014. 208 s. URL : https://www.ereading.club/bookreader.php/1054373/ Karpa_Baby_travel._Podorozhi_z\%A0ditmi\%2C_abo_Yak_ne_stati_kurkoyu.html

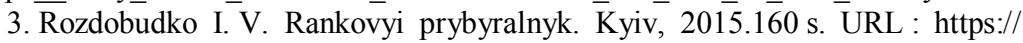
www.rulit.me/books/rankovij-pribiralnik-read-374098-1.html

Стаття надійшла до редакиії 15.09.2019 p. Прийнята до друку 19.11.2019 p. 